\title{
An outbreak of caprine toxoplasmosis - investigation and case report
}

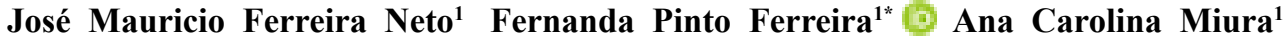 \\ Jonatas Campos de Almeida ${ }^{1}$ Felippe Danyel Cardoso Martins ${ }^{1}$ Marielen de Souza ${ }^{1}$ \\ Dalton Evert Bronkhorst ${ }^{2}$ Paulo Roberto Romanelli ${ }^{1}$ Aline Kuhn Sbruzzi Pasquali ${ }^{1}$ \\ Hannah Lia Ettiene Peruch Lemos dos Santos ${ }^{1}$ Aline do Nascimento Benitez ${ }^{1}$ \\ Eloiza Teles Caldart ${ }^{1}$ Luiz Francisco Zanella ${ }^{1}$ Roberta Lemos Freire ${ }^{1}$ Italmar Teodorico Navarro $^{1}$
}

${ }^{1}$ Laboratório de Zoonoses e Saúde Pública, Departamento de Medicina Veterinária Preventiva, Universidade Estadual de Londrina (UEL), Rodovia Celso Garcia Cid/PR 445, km 380, 86057-970, Londrina, PR, Brasil. E-mail: nandaferreiravet@gmail.com. "Corresponding author. ${ }^{2}$ Universidade do Norte do Paraná (UNOPAR), Arapongas, PR, Brasil.

ABSTRACT: The present study aimed to investigate an abortion outbreak in a dairy goat herd in the municipality of Arapoti, Parana, Brazil. At the beginning of the outbreak, blood samples were collected from 33 goats with clinical signs; later, of the whole goat herd, two cats and two dogs. Milk samples were collected from 78 lactating goats. Four environmental soil samples and four samples of feed residue from goat feeders were collected too. Immunofluorescence antibody test (IFA) was used for serodiagnosis, the molecular analysis was conducted by means of the polymerase chain reaction (PCR), for the isolation of the etiological agent the bioassay was used. The results of the IFA revealed that 76.53\% (137/179) of the goats, two dogs and two cats were seropositive for Toxoplasma gondii. Bioassay revealed one buffy coat and two milk sample having viable T. gondii. In the PCR, 11 whole blood samples, eight milk, three feeder troughs, and all soil samples were positive. The findings of the present study confirmed an outbreak caused by environmental contamination (of soil and feed) with T. gondii oocysts that could have been shed by kittens that lived on the farm and had access to the stock of goat food, facilitating this contamination, which reinforces the need for veterinary assistance and good management practices on farms.

Key words: toxoplasma, goats. IFA, PCR, bioassay.

Surto de toxoplasmose caprina - investigação e relato de caso

RESUMO: O presente estudo teve como objetivo investigar um surto de aborto em um rebanho de cabras leiteiras no municipio de Arapoti, Paraná, Brasil. No início do surto, foram coletadas amostras de sangue de 33 cabras com sinais clinicos; mais tarde, de todo o rebanho caprino, dois gatos e dois cachorros. Foram obtidas amostras de leite das 78 cabras em lactação. Quatro amostras ambientais de solo e quatro de resíduos de comedouro também foram coletadas. O teste de imunofluorescência (IFI) foi utilizado para o sorodiagnóstico, a análise molecular foi conduzida por meio da reação em cadeia da polimerase (PCR), para isolamento do agente etiológico utilizou-se o bioensaio. Os resultados da IFI revelaram que 76,53\% (137/179) das cabras, todos os cães e gatos eram soropositivos para Toxoplasma gondii. O bioensaio revelou uma amostra de camada leucocitária e duas de leite contaminadas com T. gondii viável. Na PCR, 11 amostras de sangue total, oito de leite, três resíduos alimentares e todas as amostras de solo foram positivas. Os resultados do presente estudo confirmaram um surto causado por contaminação ambiental (de solo e alimentos) com oocistos de T. gondii que, provavelmente, foram eliminados por gatos que permaneceram na fazenda e tinham acesso ao estoque de alimento dos caprinos, reforçando a necessidade de assistência técnica veterinária e boas práticas de manejo.

Palavras-chave: toxoplasma, cabras. IFI, PCR, bioensaio.

Toxoplasmosis is a widespread disease that could affect all warm-blooded animals worldwide, its etiological agent is the protozoan Toxoplasma gondii (NICOLLE \& MANCEAUX, 1909) and its definitive hosts are members of the Felidae family (FRENKEL, 1971). The parasite can be transmitted to humans and animals mainly through: the fecal-oral route, through the ingestion of oocysts that may be present in contaminated water, soil and vegetables; consumption of raw or undercooked meat and animal products containing tissue cysts; and transplacental route (FRENKEL et al, 1970). Caprines are susceptible species to clinical toxoplasmosis and they can be major sources of infection to humans, through the consumption of raw or under cooked meat, raw milk and its by-products (DUBEY et al., 2014). The main route of transmission for goats is via the ingestion of oocysts of the parasites from contaminated water and 
pasture (DUBEY, 2010). The present study aimed to investigate an abortion outbreak in a dairy goat herd in the municipality of Arapoti, Parana, Brazil.

The study was conducted on a farm in the county of Arapoti, located at $24^{\circ} 09^{\prime} 28^{\prime \prime} \mathrm{S}$ latitude and $49^{\circ} 99^{\prime} 37^{\prime \prime} \mathrm{W}$ longitude, under conditions of a subtropical climate and Atlantic Forest biome, East Central Parana mesoregion. The herd of the farm under investigation was composed of 179 Saanen goats as follows: 78 lactating, one breeder, 65 young females ( $\leq 6$ months), and 35 young males ( $\leq 6$ months).

The toxoplasmosis outbreak occurred between the month of September and October 2013. The following clinical signs were observed in 33 animals: lymphadenopathy, diarrhea, piloerection, apparent weight loss, abortion in six females in the late third trimester of pregnancy, and birth of weak offspring that either died during the first week of life or showed clinical signs, such as rectal obstruction, hyperemia, diarrhea, and blindness. Around $60 \%$ of the females exhibited reproductive disorders, such as: difficulty to conceive and return to estrus. The death of three goats were reported, two of that had paddling movements. When the farm was visited, kittens were allowed to roam the milking room, storage area for feed, and the area in which the goat feeders were located.

In October, blood samples were collected in two stages with 20 days of interval. During the first stage, blood samples were collected from $18.4 \%$ of the animals (33/179), those that exhibited clinical signs. During the second stage, in the same month, blood samples from all 179 goats, two adult dogs, and two kittens were collected in two tubes, one with and one without anticoagulant. Also in the second stage, $50 \mathrm{~mL}$ of milk samples were collected from all lactating animals, eight environmental samples were collected, four soil samples from the habitat of the kittens and four feed samples from troughs. Due to the difficulty in accessing the cats, the faeces were not collected. Abortions were discarded by the farmer, making it impossible to analyze them. An epidemiological questionnaire was used to obtain information about individual and sanitary characteristics about the animals and the farm.

Serum samples were subjected to the immunofluorescence assay (IFA) according to CAMARGO (1973), using species-specific anti-goat IgG conjugate; tachyzoites of $T$. gondii $\mathrm{RH}$ strain were used as the antigen. In addition, a positive control and a negative control were included in each slide. Goats with antibody titers $\geq 64$ were considered positive (NAVARRO et al., 1992) and the cutoff point in dogs, cats, and mice was $\geq 16$ (GARCIA et al., 1999). The first set of serum samples collected from the goats was diluted in a ratio of 1:4 and tested until a result of negative serum titration was obtained. However, the second set of samples collected from caprines, felines, and canines, were tested until titers $\geq 4,096$ were obtained. To attend to $3 \mathrm{R}$ 's principles in use of experimental animals, we only used buffy coat and milk of goats that yielded titers $\geq 4,096$ in the IFA, totaling 128 Swiss albino mice inoculated subcutaneously, method described by DUBEY (2010). Mice were daily observed for symptoms (bristly hair, tearing, weight loss, diarrhea and abdominal distension). Forty-five days after inoculation, the mice were euthanized following guidelines established by Nacional Council for Animal Experimental Control (CONCEA/Brazil), concerning about minimize potential pain, suffering and distress. Blood samples were collected for antibody detection by IFA, the brain was used for identification of tissue cysts by optical microscopy; organ samples, from positive animals as determined by the IFA, were subjected to polymerase chain reaction (PCR) analysis and re-inoculation. DNA extraction from buffy layer and milk, from the tissues (organs and brain) and from environmental samples were performed according to the manufacturer recommendations using the following kits: Mini Spin Plus Extraction Kit (BIOPUR ${ }^{\mathrm{TM}}$, Paraná, Brazil, Pure Link ${ }^{\mathrm{TM}}$ Genomic DNA Mini Kit (Invitrogen, Califórnia, USA) and NucleoSpin Tissue DNA Extraction Kit (Macherey-Nagel, Bethlehem, USA), respectively. For the environmental samples, previous thermal treatment ( 5 cycles of freezing at $-80{ }^{\circ} \mathrm{C}$ and thawing at $56{ }^{\circ} \mathrm{C}$ water bath). A fragment of $529 \mathrm{bp}$ was amplified in PCR for detection of T. gondii DNA using the pair of primers: TOX4 (CGCTGCAGGGAGGAAGACGAAAGTTG) and TOX5 (CGCTGCAGACACAGTGCATC TGGATT), for each ten samples on the plate, one positive control of the PCR and one negative of the extraction and one of the PCR were used, described by HOMAN et al. (2000). Statistical analysis of associations among results of serology, data obtained from the epidemiological questionnaire, and observations made at the location of the outbreak, was performed using the EPIINFO 3.5.4 software (DEAN et al., 1994). The chi-square test with Yates correction or Fisher's Exact test were used for analysis of the differences between two proportions, considering a significance level of $5 \%$.

The prevalence of anti- $T$. gondii antibodies in the first stage collection in goats was $66.6 \%(21 / 33)$ and in the second stage was $76.5 \%(137 / 179)$, more details in figure 1. A significant increase $(p=0.01)$ in 


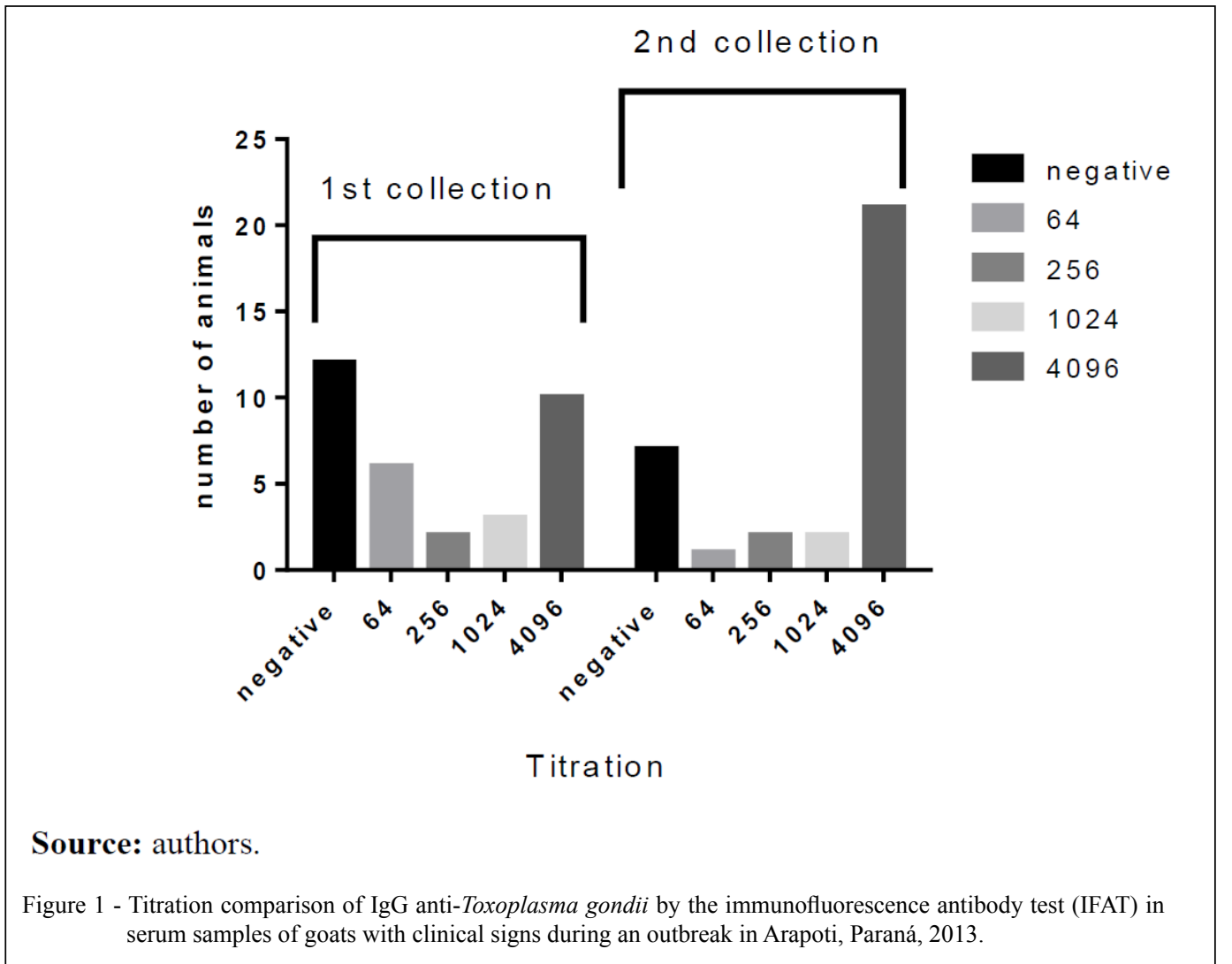

the percentage of positive animals with titers $\geq 4,096$ was observed between the first and second set of blood samples. All cats $(2 / 2)$ and all dogs (2/2) were also positive, with titers $\geq 1024$. In the bioassay, one buffy coat and one milk sample tested positive, when the sera of inoculated mice were subjected to the IFA; in the PCR, pooled organs of one mice inoculated with one milk sample were also positive (Table 1). No tissue cysts were observed by optical microscopy in brain of mice. The presence of $T$. gondii DNA was observed in $27.5 \%$ (11/40) of buffy coat samples of positive animals with titers $\geq 4,096,50.0 \%$ (8/16) of milk samples from goats with titers $\geq 1,024$ and all four soil samples and three of the four feed samples of waste from goat feeders (Table 1). Significant differences were observed between prevalence in different categories: young goats exhibited a lower prevalence compared to other caprine $(\mathrm{p}<0.01)$, and also when compared with young females $(p<0.01)$.

Similar results have been reported by SILVA FILHO et al. (2008), who investigated an outbreak that affected 304 caprine in Paraná, where they observed high titers of anti- $T$. gondii antibodies, with a prevalence of $89.1 \%$, positive bioassay of

Table 1 - Bioassay results of mice inoculated with caprine samples (milk and buffy coat), and PCR of milk and buffy coat of goats, soil, and feed residues from troughs in Arapoti, Paraná, Brazil, 2013.

\begin{tabular}{lcccccc}
\hline & Bioassay - Milk & Bioassay - Buffy coat & PCR - Milk & PCR - Buffy coat & PCR - Soil & PCR - Troughs \\
\hline${ }^{*}$ IFAT & $1 / 19^{\mathrm{a}}$ & $1 / 19$ & - & - & - & - \\
"PCR & $1 / 1$ & ne $^{\mathrm{b}}$ & $8 / 16$ & $11 / 40$ & $4 / 4$ & $3 / 4$ \\
\hline
\end{tabular}

${ }^{\text {a }}$ Positives/total tested

be $=$ not evaluated

Source: authors. 
aborted fetuses and characteristic clinical signs. These findings are consistent with those of other reports by CHIARI et al. (1987) in Minas Gerais and ŠLOSÁRKOVÁ et al. (1999) in the Czech Republic, who investigated toxoplasmosis outbreaks in goats and based on the IFA reported high prevalence rates of $92.4 \%$ (317/343), and 65.9\% (29/44), respectively. From the first to the second set of samples, we observed a significant increase in titers from animals with clinical signs, which revealed active outbreak. High titers can be detected in acute infections and sudden outbreaks of toxoplasmosis, according to SILVA FILHO et al. (2008). Those authors stated that abortion outbreaks in goats associated with titers $\geq 1,024$ might indicate that $T$. gondii is the causative agent and reported that females with titers $\geq 1,024$ had a 10 times greater chance of abortion compared to those with lower titers. In the present study, $69.3 \%$ of all animals yielded titers $\geq 1,024$, with some yielding values of over one million, diluted sample to negativity. Positive results of the bioassay and PCR of buffy coat and goat milk alluded to the risk of parasite transmission through the consumption of animal by-products. VITOR et al. (1999) reported that elimination of tachyzoites in milk could last for up to 434 days, DUBEY et al. (2014) demonstrated the survival of $T$. gondii tachyzoites both in goats' milk and of fresh cheese. The high risk of $T$. gondii transmission to consumers has been demonstrated on the farm since the products were sold without pasteurization. This sale has been discontinued after the results have been reported by this study and orientations about toxoplasmosis prevention were done. Environmental contamination in the proximity of the caprine and kittens' access to their habitat might be related to differences in prevalence among the various categories studied. Category of young males had a lower seroprevalence and the lowest titration index $(\geq 1,024)$, they remained in one area and had no access to the nearby habitat of the kittens, whereas the young and adult females had free access to these locations. As SANTOS et al. (2010) and DU et al. (2012) argue, environments frequented by cats can be widely contaminated with oocysts of $T$. gondii and farms with a higher number of cats are generally the most contaminated. GARCIA et al. (2012) reported that access of cats to feed intended for goats was considered a risk factor for T. gondii infection in a herd. All goats on the farm were reared under semi-intensive management, GARCIA et al. (2012) demonstrated that semi-intensive management is a risk factor for infection with $T$. gondii; environmental contamination with oocysts was evidenced by the positive PCR results obtained on the samples of soil and left over feed in the trough, both of which represent transmission paths. DUBEY (1998) reported oocyst survival of 54 months in water at temperatures below $4{ }^{\circ} \mathrm{C}$; 13 months at $0{ }^{\circ} \mathrm{C}$; and 106 days at $-5{ }^{\circ} \mathrm{C}$ and $-10{ }^{\circ} \mathrm{C}$; further stated that the oocysts did not lose infectivity for 200 days when maintained at temperatures between $10^{\circ} \mathrm{C}$ and $25^{\circ} \mathrm{C}$.

Toxoplasma gondii infections in goat herds are relevant to both public health and the development of goat breeding. The findings of the present study, including the high seroprevalence of anti- $T$. gondii antibodies, positive bioassay and PCR positivity in buffy coat, milk, soil and feed residues in feeding troughs, which are clinical signs of toxoplasmosis. This confirmed an outbreak caused by environmental contamination (of soil and food) with $T$. gondii oocysts that were likely eliminated by kittens that remained on the farm and had access to the stock of goat food, reinforcing the need for veterinary technical assistance and good management practices.

\section{ACKNOWLEDGEMENTS}

We are grateful to Coordenação de Aperfeiçoamento de Pessoal de Nível Superior (CAPES) for the scholarship.

\section{BIOETHICS AND BIOSSECURITY COMMITTEE APPROVAL}

This survey was conducted in accordance with the criteria and requirements of the Ethics Commission on Animal Use of Empresa Brasileira de Pesquisa Agropecuária (EMBRAPA) and approved under protocol 010/2014.

\section{DECLARATION OF CONFLICTING INTERESTS}

We have no conflict of interest to declare.

\section{REFERENCES}

CAMARGO, M. E. Introdução às técnicas de imunofluorescência. Revista Brasileira de Patologia Clínica, v. 10, n. 4, p. 143-171, 1973.

CHIARI, C. A.; et al. Soro-epidemiologia da toxoplasmose caprina em Minas Gerais, Brasil. Arquivo Brasileiro de Medicina Veterinária e Zootecnia, v. 39, p. 587-609, 1987.

DEAN, A. G.; et al. Epi Info, Version 6: a word processing, data bases, and statistic program for epidemiology on microcomputers. Atlanta, Georgia: Center for Diseases Control and Prevention, 1994.

DU, F.; et al. Survey on the contamination of Toxoplasma gondii oocysts in the soil of public parks of Wuhan, China. Veterinary Parasitology, v. 184, n. 2-4, p. 141-146, 2012. Avaliable from: <https://www.sciencedirect.com/science/article/ 
pii/S0304401711005723>. Accessed: apr. 03, 2018. doi: 10.1016/j. vetpar.2011.08.025.

DUBEY, J. P. Toxoplasma gondii oocyst survival under defined temperatures. The Journal of parasitology, v. 84, n. 4, p. 862-5, 1998. Avaliable from: $<$ http://www.jstor.org/stable/3284606?seq=1\#page scan_tab_contents $>$. Accessed: apr 03, 2018. doi: 10.2307/3284606.

DUBEY, J. P. Toxoplasmosis of animals and humans. 2. ed. Maryland, USA: CRC Press, 2010. Available from: $<$ https://www. sciencedirect.com/science/article/pii/S0304401711005723>. Accessed: apr 3, 2018. doi: 10.4315/0362-028X.JFP-14-167.

DUBEY, J. P.; et al. Detection and Survival of Toxoplasma gondii in Milk and Cheese from Experimentally Infected Goats. Journal of food protection, v. 77, n. 10, p. 1747-1753, 2014. Available from: <http:// jfoodprotection.org/doi/abs/10.4315/0362-028X.JFP-14-167?code=foprsite >. Accessed: apr 3, 2018. doi: 10.1016/j.vetpar.2011.08.025.

FRENKEL, J. K. Toxoplasmosis: mechanisms of infection, laboratory diagnosis and management. Current Topics in Pathology, v. 50, p. 29-75, 1971

FRENKEL, J. K.; et al. Toxoplasma gondii in cats: fecal stages identified as coccidian oocysts. Science (New York, N.Y.), v. 167, n. 3919, p. 893-896, 1970. Avaliable from: <http://science.sciencemag. org/content/167/3919/893>. Accessed: apr 3, 2018. doi: 10.1126/ science.167.3919.893.

GARCIA, G.; et al. Toxoplasma gondii in goats from Curitiba, Paraná, Brazil: risks factors and epidemiology. Revista Brasileira de Parasitologia Veterinária, v. 21,n. 1, p. 42-47,2012. Avaliable from: <http:/www.scielo.br/ scielo.php?pid=S1984-29612012000100009\&script=sci arttext\&tlng=es $>$. Accessed: apr 3, 2018. doi: 10.1590/S1984-29612012000100009.

GARCIA, J. L.; et al. de. Soroepidemiologia da toxoplasmose em gatos e cães de propriedades rurais do município de Jaguapitã, estado do Paraná, Brasil. Ciência Rural, v. 29, n. 1, p. 99-104, 1999. Avaliable from: <http://www.scielo.br/pdf/\%0D/cr/v29n1/a18v29n1. pdf $>$. Accessed: apr 3, 2018.
HOMAN, W. L.; et al. Identification of a 200- to 300-Fold Repetitive 529 Bp DNA Fragment in Toxoplasma gondii, and Its Use for Diagnostic and Quantitative PCR. International journal for parasitology, v. 30, n. 1, p. 69-75, 2000. Avaliable from: $<$ https://www.sciencedirect.com/ science/article/pii/S0020751999001708>. Accessed: apr 3, 2018. doi: 10.1016/S0020-7519(99)00170-8

NAVARRO, I. T.; et al. Toxoplasma gondii isolamento a partir de carne e cérebro de suínos comercializados na região de Londrina-PR. Semina: Ciências Agrárias, v. 13, n. 1, p. 32, 1992. Available from: <http:// www.uel.br/revistas/uel/index.php/semagrarias/article/view/4594>. Accessed: apr 3, 2018. doi: 10.5433/1679-0359.1992v13n1p32.

NICOLLE, C. J. H.; MANCEAUX, L. Sur un protozoaire nouveau du gondi. Comptes Rendus de l'Académie des Sciences, n. 148, p. 369-372, 1909.

SANTOS, T. R.; et al. Detection of Toxoplasma gondii oocysts in environmental samples from public schools. Veterinary Parasitology, v. 171, n. 1-2, p. 53-57, 2010. Available from: <https:// www.sciencedirect.com/science/article/pii/S030440171000138X>. Accessed: apr 3, 2018. doi: 10.1016/j.vetpar.2010.02.045.

SILVA FILHO, M. D. F.; et al. Toxoplasma gondii: abortion outbreak in a goatherd from Southern Brazil. Semina: Ciências Agrárias, v. 29 , n. 4, p. 887, 2008. Available from: <http://www.uel.br/revistas/ uel/index.php/semagrarias/article/view/2724>. Accessed: apr 3, 2018. doi: $10.5433 / 1679-0359.2008 v 29 n 4 p 887$.

ŠLOSÁRKOVÁ, S. et al. Toxoplasmosis and iodine deficiency in Angora goats. Veterinary Parasitology, v. 81, n. 2, p. 89-97, 1999. Available from: $<$ https://www.sciencedirect.com/science/article/pii/ S0304401798002441>. Accessed: apr 3, 2018. doi: 10.1016/S03044017(98)00244-1.

VITOR, R. W. et al. Antibody response in goats experimentally infected with Toxoplasma gondii. Veterinary Parasitology, v. 81, n. 3, p. 259-263, 1999. Avaliable from: <https://www.sciencedirect.com/ science/article/pii/S0304401798002519>. Accessed: apr 3, 2018. doi: 10.1016/S0304-4017(98)00251-9. 